\title{
The role of potassium atoms in the formation of uranyl selenates: the crystal structure and synthesis of two novel compounds
}

\author{
Vladislav V. GURZHIY1,*, Olga S. TYUMENTSEVA', llya V. KORNYAKOV', Sergey V. KRIVOVICHEV', \\ Ivan G. TANANAEV²
${ }^{1}$ Department of Crystallography, Geological Faculty, St. Petersburg State University, University Emb. 7/9, St. Petersburg, 199034, Russian Federation; vladgeo17@mail.ru
${ }^{2}$ Frumkin Institute of Physical Chemistry and Electrochemistry RAS, Leninskiy pr. 31, Block 4, Moscow, 119991, Russian Federation \\ * Corresponding author
}

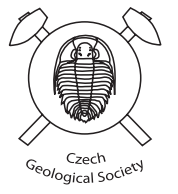

\begin{abstract}
Single crystals of two new uranyl selenates $\mathrm{K}_{3}\left(\mathrm{H}_{3} \mathrm{O}\right)\left[\left(\mathrm{UO}_{2}\right)_{4}\left(\mathrm{SeO}_{4}\right)_{6}\left(\mathrm{H}_{2} \mathrm{O}\right)_{4}\right] \cdot 5 \mathrm{H}_{2} \mathrm{O}(\mathrm{I})$ and $\mathrm{K}_{2.5}\left(\mathrm{NO}_{3}\right)_{0.5}\left[\left(\mathrm{UO}_{2}\right)_{2}\left(\mathrm{SeO}_{4}\right)_{3}\right.$ $\left.\left(\mathrm{H}_{2} \mathrm{O}\right)\right] \cdot 4 \mathrm{H}_{2} \mathrm{O}(\mathrm{II})$ have been prepared by room-temperature evaporation from aqueous solution of uranyl nitrate, selenic acid, potassium carbonate and (for the compound $\mathbf{I}$ ) carbamide. The crystal structure of $\mathbf{I}$ has been solved by direct methods [monoclinic, $P 2_{1} / m, a=12.001(3), b=13.613(3), c=13.753(3) \AA, \beta=109.187(4)^{\circ}, V=2122.0(8) \AA^{3}$ and $\left.Z=2\right]$ and refined to $R_{1}=0.029\left(w R_{2}=0.084\right)$ for 4865 reflections with $|F \mathrm{o}| \geq 4 \sigma F$ using least-square methods. The crystal structure of II has been solved by direct methods [monoclinic, $C 2 / c, a=20.290(4), b=10.380(2), c=21.436(4) \AA, \beta=$ 103.446(3) $)^{\circ}, V=4391.0(13) \AA^{3}$ and $\left.Z=4\right]$ and refined to $R_{1}=0.027\left(w R_{2}=0.066\right)$ for 7944 reflections with $\left|F_{0}\right| \geq 4 \sigma F$ using least-square techniques. The structures of $\mathbf{I}$ and $\mathbf{I I}$ are based upon the $\left[\left(\mathrm{UO}_{2}\right)_{2}\left(\mathrm{SeO}_{4}\right)_{3}\left(\mathrm{H}_{2} \mathrm{O}\right)_{2}\right]^{2-}$ and $\left[\left(\mathrm{UO}_{2}\right)_{2}\left(\mathrm{SeO}_{4}\right)_{3}\left(\mathrm{H}_{2} \mathrm{O}\right)\right]^{2-}$ layers, respectively, consisting of $\mathrm{UO}_{7}$ pentagonal bipyramids sharing corners with $\mathrm{SeO}_{4}$ tetrahedra. Potassium cations induce curvature of the uranyl selenate layers, which is mediated by the interlayer water molecules, hydronium ions and nitrate groups. The topology of the 2D units in the structure of $\mathbf{I}$ is novel for the structural chemistry of uranyl selenates.
\end{abstract}

Keywords: uranyl selenates, potassium, crystal structure, topology, single-crystal X-ray diffraction

Received: 21 November 2013; accepted: 20 March 2014; handling editor: J. Plášil

The online version of this article (doi: 10.3190/jgeosci.165) contains supplementary electronic material.

\section{Introduction}

The problem of safe disposal of spent nuclear fuel is responsible for the increasing interest in the study of secondary uranium-bearing compounds. Understanding the formation of natural and synthetic uranium phases is important for modelling of alteration processes occurring in the uranium deposits and geological radioactive waste repositories (Finch et al. 1999). Nowadays seven uranyl selenites are known as mineral species (Burns 2005; Krivovichev and Plášil 2013), whereas no uranium selenates have been found in nature to date. This can be explained by both high solubility of uranyl selenates in aqueous solutions and easy reduction of $\mathrm{Se}^{6+}$ to the $\mathrm{Se}^{4+}$ state under common natural conditions (Charykova et al. 2010, 2012; Krivovichev et al. 2011a, 2012). Synthetic members of the uranyl selenate group display an outstanding structural diversity. There are more than 120 purely inorganic or organically templated inorganic uranyl selenates (Burns 2005; Krivovichev et al. 2007; Krivovichev and Plášil 2013). Most of the uranylcontaining compounds, in particular uranyl selenate structures, are layered due to the specific coordination of U(VI) atoms (Burns et al. 1997). There are also wellknown compounds with isolated, chain or framework structural units (Krivovichev et al. 2007; Krivovichev 2008 , 2013). However, the most remarkable compounds in this group are uranyl selenate nanotubules (Krivovichev et al. 2005a, b; Alekseev et al. 2008), which have a unique structural architecture considered as being generated by folding of flat $2 \mathrm{D}$ units into single tubes. It is interesting that compounds containing nanotubules invariably contain $\mathrm{K}^{+}$ions in their structures. As it was suggested in the recent works (Krivovichev et al. 2009, 2011b; Krivovichev 2010), the presence of these ions plays a crucial role in formation of tubular morphologies of structural units, whereas water molecules in the interlayer space reduce the folding effect and may totally neutralize the curvature of uranyl selenate layers. There are eight K-containing uranyl selenates known so far (Krivovichev et al. 2005a, b; Alekseev et al. 2008; Gurzhiy et al. 2009, 2011, 2012; Ling et al. 2010), and it seems worthwhile to explore K-containing uranyl systems further in order to understand the role of $\mathrm{K}^{+}$ions in their structures and, in particular, the ability of these ions to induce curvature in otherwise planar structural units.

Herein, we report on the syntheses, crystal structures and spectroscopic investigations of two new potassium uranyl selenates: $\mathrm{K}_{3}\left(\mathrm{H}_{3} \mathrm{O}\right)\left[\left(\mathrm{UO}_{2}\right)_{4}\left(\mathrm{SeO}_{4}\right)_{6}\left(\mathrm{H}_{2} \mathrm{O}\right)_{4}\right] \cdot 5 \mathrm{H}_{2} \mathrm{O}(\mathrm{I})$ and $\mathrm{K}_{2.5}\left(\mathrm{NO}_{3}\right)_{0.5}\left[\left(\mathrm{UO}_{2}\right)_{2}\left(\mathrm{SeO}_{4}\right)_{3}\left(\mathrm{H}_{2} \mathrm{O}\right)\right] \cdot 4 \mathrm{H}_{2} \mathrm{O}$ (II). 


\section{Experimental}

\subsection{Synthesis}

Single crystals of the compounds I and II have been prepared by isothermal evaporation from aqueous solutions at room-temperature conditions. The crystals of compound $\mathbf{I}$ formed from the mixture of $2 \mathrm{ml}$ of an aqueous solution of uranyl nitrate $\left(0.48 \mathrm{~g}\right.$ of $\left.\mathrm{UO}_{2}\left(\mathrm{NO}_{3}\right)_{2} \cdot 6 \mathrm{H}_{2} \mathrm{O}\right)$, selenic acid $(0.2$ $\mathrm{ml}$ of $\left.\mathrm{H}_{2} \mathrm{SeO}_{4}\right)$, potassium carbonate $\left(0.068 \mathrm{~g}\right.$ of $\left.\mathrm{K}_{2} \mathrm{CO}_{3}\right)$, and carbamide $\left(0.018 \mathrm{~g}\right.$ of $\left.\mathrm{CH}_{4} \mathrm{ON}_{2}\right)$. Prepared solution was heated at $60{ }^{\circ} \mathrm{C}$ for $35 \mathrm{~min}$ and then placed in a fume hood, where yellow-green crystals suitable for X-ray structural analysis grew within 6 days. Crystals of compound II formed from the mixture of $2 \mathrm{ml}$ of an aqueous solution of uranyl nitrate $\left(0.2 \mathrm{~g}\right.$ of $\left.\mathrm{UO}_{2}\left(\mathrm{NO}_{3}\right)_{2} \cdot 6 \mathrm{H}_{2} \mathrm{O}\right)$, selenic acid $\left(0.2 \mathrm{ml}\right.$ of $\left.\mathrm{H}_{2} \mathrm{SeO}_{4}\right)$ and potassium carbonate $(0.048 \mathrm{~g}$ of $\mathrm{K}_{2} \mathrm{CO}_{3}$ ). The solution was heated at $60{ }^{\circ} \mathrm{C}$ for $35 \mathrm{~min}$ and then placed in a fume hood, where yellow-green crystals suitable for X-ray structural analysis grew after 4 days.

\subsection{X-ray diffraction}

Single yellow-green plates of I and II were mounted on thin glass fibres for X-ray diffraction analysis, which was carried out using a Bruker SMART single-crystal X-ray

Tab. 1 Crystallographic data and refinement parameters for $\mathrm{K}_{3}\left(\mathrm{H}_{3} \mathrm{O}\right)\left[\left(\mathrm{UO}_{2}\right)_{4}\left(\mathrm{SeO}_{4}\right)_{6}\left(\mathrm{H}_{2} \mathrm{O}\right)_{4}\right] \cdot 5 \mathrm{H}_{2} \mathrm{O}(\mathrm{I})$ and $\mathrm{K}_{25}\left(\mathrm{NO}_{3}\right)_{05}\left[\left(\mathrm{UO}_{2}\right)_{2}\left(\mathrm{SeO}_{4}\right)_{3}\left(\mathrm{H}_{2} \mathrm{O}\right)\right] \cdot 4 \mathrm{H}_{2} \mathrm{O}(\mathrm{II})$

\begin{tabular}{|c|c|c|}
\hline Parameter & I & II \\
\hline$a(\AA)$ & 12.001(3) & $20.290(4)$ \\
\hline$b(\AA)$ & 13.613(3) & $10.380(2)$ \\
\hline$c(\AA)$ & $13.753(3)$ & $21.436(4)$ \\
\hline$\beta\left(^{\circ}\right)$ & $109.187(4)$ & 103.446(3) \\
\hline$V\left(\AA^{3}\right)$ & $2122.0(8)$ & $4391.0(13)$ \\
\hline Space group & $P 2_{1} / m$ & $C 2 / c$ \\
\hline$\mu, \mathrm{mm}^{-1}$ & 20.770 & 20.278 \\
\hline Z & 2 & 4 \\
\hline $\mathrm{D}_{\text {calc }}, \mathrm{g} \mathrm{cm}^{-3}$ & 3.467 & 3.593 \\
\hline Crystal size, $\mathrm{mm}^{3}$ & $0.23 \times 0.15 \times 0.07$ & $0.25 \times 0.16 \times 0.09$ \\
\hline Radiation & $\operatorname{MoK}_{\alpha}$ & $\operatorname{MoK}_{\alpha}$ \\
\hline Total number of reflections & 28491 & 33030 \\
\hline Number of unique reflections & 6432 & 7944 \\
\hline $2 \theta$ range, deg & 3.14-60.00 & $3.90-65.00$ \\
\hline Reflections with $\left|F_{0}\right| \geq 4 \sigma F$ & 4865 & 6405 \\
\hline$R_{\mathrm{int}}$ & 0.0561 & 0.0548 \\
\hline $\mathrm{R}_{\sigma}$ & 0.0467 & 0.0429 \\
\hline$R_{1}\left(\left|F_{0}\right| \geq 4 \sigma F\right)$ & 0.0289 & 0.0268 \\
\hline$w R_{2}\left(\left|F_{o}\right| \geq 4 \sigma F\right)$ & 0.0837 & 0.0657 \\
\hline$R_{1}$ (all data) & 0.0431 & 0.0390 \\
\hline$w R_{2}$ (all data) & 0.0867 & 0.0685 \\
\hline$S$ & 1.036 & 1.040 \\
\hline$\rho_{\min ,} \rho_{\max }, \mathrm{e} / \AA^{3}$ & $-1.399,2.717$ & $-2.013,2.952$ \\
\hline
\end{tabular}

Note: $\mathrm{R}_{1}=\Sigma|| \mathrm{F}_{0}|-| \mathrm{F}_{c}|| \Sigma\left|\mathrm{F}_{0}\right| ; w \mathrm{R}_{2}=\left\{\Sigma\left[w\left(\mathrm{~F}_{0}^{2}-\mathrm{F}_{c}^{2}\right)^{2}\right] / \Sigma\left[w\left(\mathrm{~F}_{0}^{2}\right)^{2}\right]\right\}^{1 / 2} ; w=1 /\left[\sigma^{2}\left(\mathrm{~F}_{0}^{2}\right)+(\mathrm{aP})^{2}+\mathrm{bP}\right]$, where $\mathrm{P}=\left(\mathrm{F}_{\mathrm{o}}{ }^{2}+2 \mathrm{~F}_{\mathrm{c}}{ }^{2}\right) / 3 ; \mathrm{s}=\left\{\Sigma\left[w\left(\mathrm{~F}_{\mathrm{o}}{ }^{2}-\mathrm{F}_{\mathrm{c}}{ }^{2}\right)\right] /(\mathrm{n}-\mathrm{p})\right\}^{1 / 2}$, where $n$ is the number of reflections and $p$ is the number of the refined parameters diffractometer equipped with an APEX II CCD planar detector operated with $\mathrm{MoK}_{\alpha}$ radiation at $50 \mathrm{kV}$ and $40 \mathrm{~mA}$. More than a hemisphere of X-ray diffraction data $\left(\theta_{\max }\right.$ $=30.00$ and $32.50^{\circ}$ for $\mathbf{I}$ and $\mathbf{I I}$, respectively) were collected at $210 \mathrm{~K}$ for each crystal with frame widths of $0.5^{\circ}$ in $\omega$, and exposition of $20 \mathrm{~s}$ per each frame. Data were integrated and corrected for background, Lorentz, and polarization effects using an empirical spherical model (Bruker programs APEX and XPREP). Absorption corrections were applied using the SADABS program (Sheldrick 2007). The unit-cell parameters of I (Tab. 1) were determined and refined by the least-squares techniques on the basis of 28491 reflections with $2 \theta$ in the range of $3.14-60.00^{\circ}$. From the systematic absences and statistics of reflection distribution, the space group $P 2_{1} / m$ was determined. The structure was solved by direct methods and refined to $R_{1}=0.029\left(w R_{2}=0.084\right)$ for 4865 reflections with $\left|F_{0}\right| \geq 4 \sigma F$ using the SHELXL-97 program (Sheldrick 2008) incorporated in the OLEX2 program package (Dolomanov et al. 2009). The unit-cell parameters of II (Tab. 1) were determined and refined by the least-squares techniques on the basis of 33,030 reflections with $2 \theta$ in the range $3.90^{\circ}-65.00^{\circ}$. From the systematic absences and statistics of reflection distribution, the space group $C 2 / c$ was determined. The structure was solved by direct methods and refined to $R_{1}=0.027\left(w R_{2}=0.066\right)$ for 6405 reflections with $\left|F_{0}\right| \geq 4 \sigma F$ using the SHELXL-97 program (Sheldrick 2008) incorporated in the OLEX2 program package (Dolomanov et al. 2009). The final models included coordinates and anisotropic displacement parameters for all non-hydrogen atoms (Tabs 2 and 4 for $\mathbf{I}$ and II, respectively). Selected bond lengths and angles are given in Tabs 3 and 5 (for $\mathbf{I}$ and II, respectively). Positions of $\mathrm{H}$ atoms of $\mathrm{H}_{2} \mathrm{O}$ molecules were localized from difference Fourier maps only for II and kept fixed during refinement. Oxygen atoms O22-O26 of $\mathrm{H}_{2} \mathrm{O}$ molecules from the interlayer space of the compound I and atoms forming a nitrate group (N1, O22, O23 and O24) in the structure of II were refined with the same displacement parameters (using EADP instruction) due to a weak disorder. Supplementary crystallographic data for this paper have been deposited at 
The role of potassium atoms in the uranyl selenates crystal structure formation

Tab. 2 Coordinates and displacement parameters $\left(\AA^{2}\right)$ of atoms forming the structure of $\mathrm{K}_{3}\left(\mathrm{H}_{3} \mathrm{O}\right)\left[\left(\mathrm{UO}_{2}\right)_{4}\left(\mathrm{SeO}_{4}\right)_{6}\left(\mathrm{H}_{2} \mathrm{O}\right)_{4}\right] \cdot 5 \mathrm{H}_{2} \mathrm{O}(\mathrm{I})$

\begin{tabular}{|c|c|c|c|c|}
\hline Atom & $\mathrm{x} / \mathrm{a}$ & $\mathrm{y} / \mathrm{b}$ & $\mathrm{z} / \mathrm{C}$ & $U_{\text {eq }}$ \\
\hline$\overline{\mathrm{U}(1)}$ & $0.22847(2)$ & $0.48852(2)$ & $0.433390(17)$ & $0.01926(7)$ \\
\hline $\mathrm{U}(2)$ & $0.22135(2)$ & $0.465616(19)$ & $-0.068123(17)$ & $0.01935(7)$ \\
\hline $\operatorname{Se}(1)$ & $0.09854(6)$ & $0.49158(5)$ & $0.14632(5)$ & $0.02124(14)$ \\
\hline $\mathrm{Se}(2)$ & $-0.10023(6)$ & $0.50992(5)$ & $0.35368(5)$ & $0.01924(13)$ \\
\hline $\operatorname{Se}(3)$ & $0.49279(6)$ & $0.51073(6)$ & $0.34348(5)$ & $0.02508(16)$ \\
\hline $\mathrm{K}(1)$ & $0.0427(2)$ & $3 / 4$ & $0.26609(17)$ & $0.0307(5)$ \\
\hline $\mathrm{K}(2)$ & $0.1481(3)$ & $3 / 4$ & $0.0149(2)$ & $0.0584(8)$ \\
\hline $\mathrm{K}(3)$ & $0.0683(6)$ & $1 / 4$ & $0.3063(4)$ & $0.0469(13)$ \\
\hline $\mathrm{K}(4)$ & $0.4949(8)$ & $3 / 4$ & $0.5156(5)$ & $0.074(3)$ \\
\hline $\mathrm{O}(1)$ & $0.2501(4)$ & $0.3634(4)$ & $0.4676(4)$ & $0.0298(11)$ \\
\hline $\mathrm{O}(2)$ & $0.2028(4)$ & $0.6134(4)$ & $0.3978(4)$ & $0.0290(11)$ \\
\hline $\mathrm{O}(3)$ & $0.1974(4)$ & $0.5260(4)$ & $0.5930(3)$ & $0.0281(12)$ \\
\hline $\mathrm{O}(4)$ & $0.3649(4)$ & $0.4679(5)$ & $0.3431(4)$ & $0.0423(16)$ \\
\hline $\mathrm{O}(5)$ & $0.0250(4)$ & $0.4519(4)$ & $0.4117(3)$ & $0.0250(10)$ \\
\hline $\mathrm{O}(6)$ & $0.1262(4)$ & $0.4404(4)$ & $0.2598(3)$ & $0.0282(11)$ \\
\hline $\mathrm{O}(7)$ & $0.2891(4)$ & $0.5800(4)$ & $-0.0255(4)$ & $0.0306(12)$ \\
\hline $\mathrm{O}(8)$ & $0.1533(5)$ & $0.3530(4)$ & $-0.1126(4)$ & $0.0322(12)$ \\
\hline $\mathrm{H}_{2} \mathrm{O}(9)$ & $0.3600(5)$ & $0.4140(4)$ & $-0.1532(4)$ & $0.0391(14)$ \\
\hline $\mathrm{H}_{2} \mathrm{O}(10)$ & $0.3889(5)$ & $0.3854(5)$ & $0.0587(4)$ & $0.0413(14)$ \\
\hline $\mathrm{O}(11)$ & $0.1860(4)$ & $0.4372(4)$ & $0.0917(3)$ & $0.0290(12)$ \\
\hline $\mathrm{O}(12)$ & $0.1159(5)$ & $0.6093(4)$ & $0.1523(4)$ & $0.0344(12)$ \\
\hline $\mathrm{O}(13)$ & $-0.0387(4)$ & $0.4580(4)$ & $0.0821(3)$ & $0.0246(10)$ \\
\hline $\mathrm{O}(14)$ & $-0.0837(5)$ & $0.6277(4)$ & $0.3550(4)$ & $0.0321(12)$ \\
\hline $\mathrm{O}(15)$ & $-0.1506(4)$ & $0.4661(4)$ & $0.2347(3)$ & $0.0279(11)$ \\
\hline $\mathrm{O}(16)$ & $0.5907(4)$ & $0.4616(4)$ & $0.4463(3)$ & $0.0271(11)$ \\
\hline $\mathrm{O}(17)$ & $0.4958(6)$ & $0.6291(5)$ & $0.3469(5)$ & $0.0508(16)$ \\
\hline $\mathrm{O}(18)$ & $0.5176(5)$ & $0.4676(5)$ & $0.2417(4)$ & $0.0467(16)$ \\
\hline $\mathrm{H}_{2} \mathrm{O}(19)$ & $0.4671(8)$ & $3 / 4$ & $0.9787(7)$ & $0.050(2)$ \\
\hline $\mathrm{H}_{2} \mathrm{O}(20)$ & $0.3121(8)$ & $1 / 4$ & $0.7215(7)$ & $0.052(2)$ \\
\hline $\mathrm{H}_{2} \mathrm{O}(21)$ & $0.3877(9)$ & $3 / 4$ & $0.1572(7)$ & $0.059(3)$ \\
\hline $\mathrm{H}_{2} \mathrm{O}(22)$ & $-0.0324(12)$ & $1 / 4$ & $0.4644(7)$ & $0.086(3)$ \\
\hline $\mathrm{H}_{2} \mathrm{O}(23)$ & $0.300(3)$ & $3 / 4$ & $0.6060(15)$ & $0.086(3)$ \\
\hline $\mathrm{H}_{2} \mathrm{O}(24)$ & $0.089(3)$ & $1 / 4$ & $0.0901(15)$ & $0.086(3)$ \\
\hline $\mathrm{H}_{2} \mathrm{O}(25)$ & $0.342(3)$ & $1 / 4$ & $0.2732(15)$ & $0.086(3)$ \\
\hline $\mathrm{H}_{2} \mathrm{O}(26)$ & $0.165(3)$ & $3 / 4$ & $-0.1795(15)$ & $0.086(3)$ \\
\hline
\end{tabular}

Inorganic Crystal Structure Database (ICSD 427034 and 427035 for I and II, respectively) and can be obtained from Fachinformationszentrum Karlsruhe at http://www. fiz-karlsruhe.de/request_for_deposited_data.html.

\subsection{Infrared spectroscopy}

The infrared (IR) spectra of I and II were recorded using $\mathrm{KBr}$ pellets on the Bruker Vertex 70 spectrometer in the region $4000-300 \mathrm{~cm}^{-1}$ and are shown in Fig. 1 . The band assignment confirms that the vibrational spectroscopic data are in a good agreement with the composition and single-crystal X-ray diffraction results.

Both spectra show characteristic absorption bands at $850-390 \mathrm{~cm}^{-1}\left(392,459,816,851 \mathrm{~cm}^{-1}\right.$ for $\mathbf{I}$ and 407 , $472,818,834$ and $850 \mathrm{~cm}^{-1}$ for II, respectively) due to the presence of $\left[\mathrm{SeO}_{4}\right]^{2-}$ anions; these bands can be attributed to the stretches of the $\mathrm{Se}-\mathrm{O}$ bonds. The bands at 950-850 $\mathrm{cm}^{-1}$ (in particular 851 and $943 \mathrm{~cm}^{-1}$ for $\mathbf{I}$ and 915,931 and $950 \mathrm{~cm}^{-1}$ for II, respectively) are due to the vibrations of the $\left(\mathrm{UO}_{2}\right)^{2+}$ cations (Nakamoto 1997). It should be noted that characteristic vibrations of the oxoselenate groups and uranyl ions overlap, so they cannot be clearly separated without structure-based calculations (Čejka 1999). The diffuse bands in the range of 3520-3200 $\mathrm{cm}^{-1}\left(3196,3427\right.$ and $\left.3522 \mathrm{~cm}^{-1}\right)$ correspond to the $\mathrm{O}-\mathrm{H}$ stretching vibrations of water molecules or a strongly polarized $\mathrm{H}_{2} \mathrm{O}$ group with strong $\mathrm{H}$ bonds. The band at $1635 \mathrm{~cm}^{-1}$ documents the presence of hydronium ions in the structure of $\mathbf{I}$. Presence of the nitrate $\mathrm{NO}_{3}$ group in the structure of II is confirmed by the multiple bands at 1630 and 1270-1260 $\mathrm{cm}^{-1}$, whether the irregularly shaped band at $670 \mathrm{~cm}^{-1}$ can be assigned to vibrational modes of the $-\mathrm{NO}_{2}$ group. Wide absorbance band of irregular shape in the range of $3500-3400 \mathrm{~cm}^{-1}$ corresponds to the stretching and bending vibrations of the $\mathrm{H}_{2} \mathrm{O}$ molecules. 


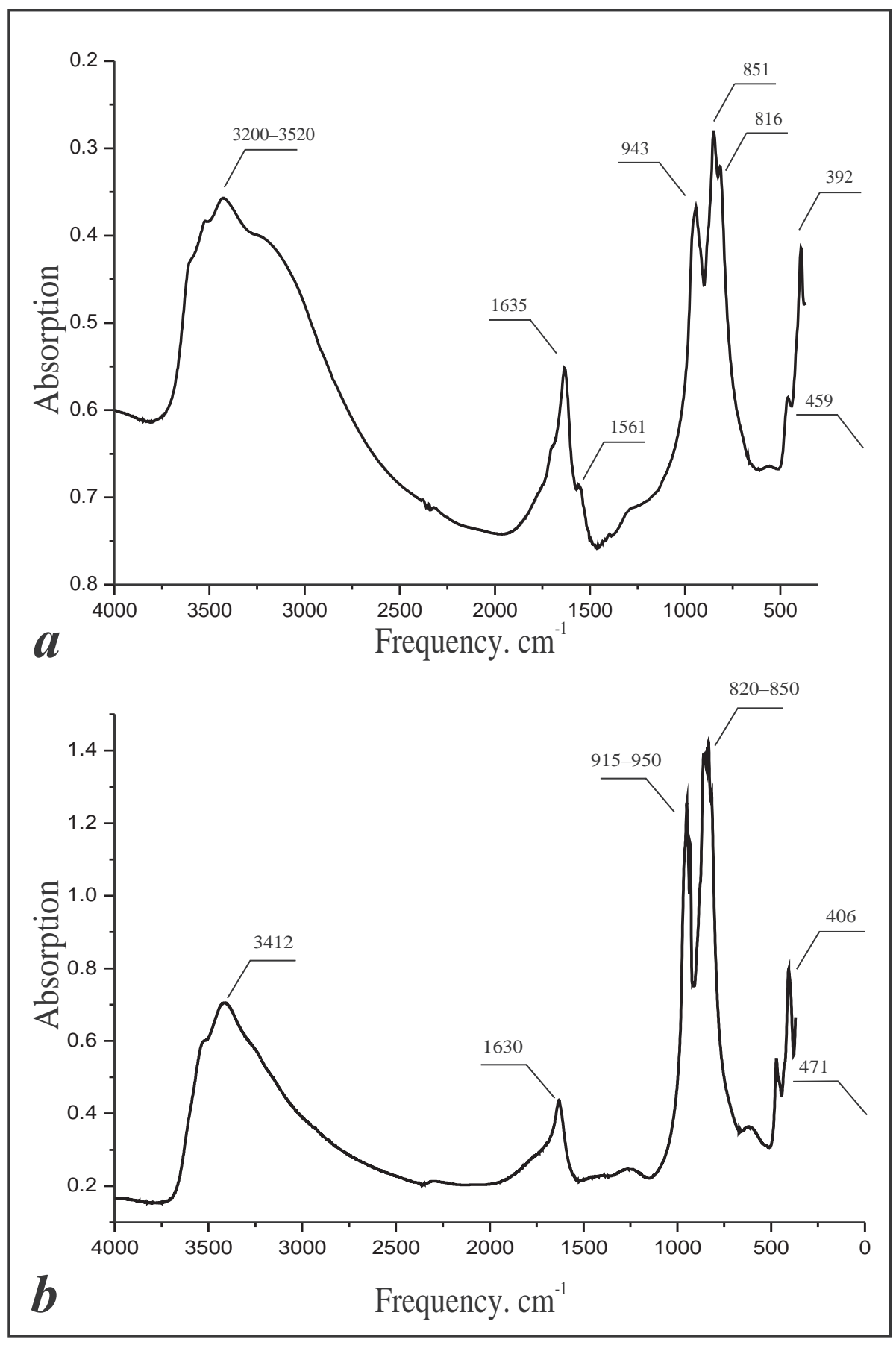

Fig. 1 Infrared spectra of $\mathrm{K}_{3}\left(\mathrm{H}_{3} \mathrm{O}\right)\left[\left(\mathrm{UO}_{2}\right)_{4}\left(\mathrm{SeO}_{4}\right)_{6}\left(\mathrm{H}_{2} \mathrm{O}\right)_{4}\right] \cdot 5 \mathrm{H}_{2} \mathrm{O}$ (a) and $\mathrm{K}_{2.5}\left(\mathrm{NO}_{3}\right)_{0.5}\left[\left(\mathrm{UO}_{2}\right)_{2}\left(\mathrm{SeO}_{4}\right)_{3}\right.$ $\left.\left(\mathrm{H}_{2} \mathrm{O}\right)\right] \cdot 4 \mathrm{H}_{2} \mathrm{O}(\mathbf{b})$

\section{Discussion}

The structure of I (Fig. 2a) contains two symmetrically independent $\mathrm{U}$ atoms with two short $\mathrm{U}^{6+}=\mathrm{O}^{2-}$ bonds (1.763(5) and 1.768(5) $\AA$ for U1 and 1.750(5) and $1.765(5) \AA$ for $\mathrm{U} 2$, respectively) forming approximately linear $\mathrm{UO}_{2}{ }^{2+}$ uranyl ions $(U r)$. The $\mathrm{U}(1) \mathrm{O}_{2}{ }^{2+}$ cation is coordinated by five oxygen atoms $\left(\mathrm{U} 1-\mathrm{O}_{e q}=\right.$
$2.355(5)-2.413(5) \AA$ ) that belong to the selenate tetrahedra and that are arranged in the equatorial plane of the $U r(1) \mathrm{O}_{5}$ pentagonal bipyramid. The $\mathrm{U}(2) \mathrm{O}_{2}{ }^{2+}$ cation is coordinated by three oxygen atoms $(2.356(5)-2.403(4) \AA)$ belonging to the selenate tetrahedra and two oxygen atoms of water molecules (the respective $\mathrm{U}(2)-\mathrm{H}_{2} \mathrm{O}(9)$ and $\mathrm{U}(2)-\mathrm{H}_{2} \mathrm{O}(10)$ bonds are elongated (2.432(5) $\AA$ and 2.444(5) $\AA$, respectively) compared to other $\mathrm{U}-\mathrm{O}_{e q}$ bonds, which is typical of hydrated uranyl complexes. Three symmetrically non-equivalent $\mathrm{Se}^{6+}$ atoms are tetrahedrally coordinated by four $\mathrm{O}^{2-}$ atoms each. The $\left[\mathrm{Se} 1 \mathrm{O}_{4}\right]^{2-}$ and $\left[\mathrm{Se}^{2} \mathrm{O}_{4}\right]^{2-}$ groups are tridentate and $\left[\mathrm{Se}^{2} \mathrm{O}_{4}\right]^{2-}$ groups are bidentate, sharing two and three vertices with adjacent uranium polyhedra, respectively. The $\mathrm{Se}-\mathrm{O}$ bond lengths for the bridging oxygen atoms fall in the range of 1.641(4)-1.657(5) $\AA, 1.642(4)-1.658(4) \AA$ and $1.640(5)-1.654(5) \AA$ for Se(1), Se(2) and Se(3), respectively. Bond lengths for the terminal oxygen atoms are shorter and are equal to 1.614(5) $\AA, 1.616(5) \AA$ and 1.612(6)-1.633(5) A for Se(1), $\mathrm{Se}(2)$ and Se(3), respectively. The difference between $\mathrm{Se}-\mathrm{O}$ bond-lengths for shared and non-shared $\mathrm{O}$ atoms is typical of uranyl oxysalts with hexavalent tetrahedrally coordinated cations (Krivovichev 2013). Non-shared vertices of the selenate tetrahedra are oriented either up or down relative to the planes of the layers.

The structure of $\mathbf{I}$ is based upon the $\left[\left(\mathrm{UO}_{2}\right)_{2}\left(\mathrm{SeO}_{4}\right)_{3}\right.$ $\left.\left(\mathrm{H}_{2} \mathrm{O}\right)_{2}\right]^{2-}$ uranyl selenate layers formed by linkage of $\mathrm{U}$ and Se coordination polyhedra via common $\mathrm{O}$ atoms (Fig. 4a). The layers are parallel to (010). The charge of the layer is compensated by potassium and hydronium ions arranged in between the 2-D uranyl selenate units. 
The linkage topology of the $\mathrm{U}$ and Se coordination polyhedra can be described using graphs where $\mathrm{U}$ and Se coordination polyhedra are symbolized by the black and white nodes, respectively (Fig. 4b). The two nodes are linked by an edge if the corresponding polyhedra have a shared $\mathrm{O}$ atom. Analysis of the topology of the uranyl selenate layers using graphs (Krivovichev 2004, 2008) indicates that the topology of the 2D layers belongs to the $c c 2-2: 3-11$ type (linkage of 4-membered rings creating 12-membered rings, Fig. 4c) and it is identical to those topologies found in the structures of $\left(\mathrm{H}_{3} \mathrm{O}\right)_{2}\left[\left(\mathrm{UO}_{2}\right)_{2}\left(\mathrm{SeO}_{4}\right)_{3}\left(\mathrm{H}_{2} \mathrm{O}\right)_{2}\right]$ $\left(\mathrm{H}_{2} \mathrm{O}\right)_{3.5}$ (Krivovichev and Kahlenberg $2005 \mathrm{a})$ and $\mathrm{Rb}_{2}\left[\left(\mathrm{UO}_{2}\right)_{2}\left(\mathrm{SeO}_{4}\right)_{3}\left(\mathrm{H}_{2} \mathrm{O}\right)_{2}\right]\left(\mathrm{H}_{2} \mathrm{O}\right)_{4}$ (Krivovichev and Kahlenberg 2005b).

Crystal structure of II (Fig. 3a) contains two symmetrically independent $U$ atoms with two short $\mathrm{U}^{6+}=\mathrm{O}^{2-}$ bonds (1.763(3) and 1.765(3) $\AA$ for $\mathrm{U}(1)$ and 1.761(4) and 1.767(4) $\AA$ for $\mathrm{U}(2)$, respectively). The $\mathrm{U}(1) \mathrm{O}_{2}{ }^{2+}$ cation is coordinated by five oxygen atoms $\left(\mathrm{U} 1-\mathrm{O}_{e q}=\right.$ 2.355(3)-2.406(3) A) of selenate tetrahedra arranged in the equatorial plane. The $\mathrm{U}(2) \mathrm{O}_{2}{ }^{2+}$ cation is coordinated by four $\mathrm{O}$ atoms (2.358(3)-2.406(3) $\AA$ ) of selenate tetrahedra and one water molecule $\left(\mathrm{U}(2)-\mathrm{H}_{2} \mathrm{O}(17)\right.$ $=2.412(4) \AA)$. Three symmetrically non-equivalent $\mathrm{Se}^{6+}$ atoms are tetrahedrally coordinated by four $\mathrm{O}^{2-}$ anions, each with an average bond-length equal to $1.634,1.638$ and $1.635 \AA$ for $\mathrm{Se}(1), \mathrm{Se}(2)$ and $\mathrm{Se}(3)$, respectively. Tetrahedral complexes are tridentate having three vertices shared with the U polyhedra. Non-shared vertices of selenate tetrahedra are oriented either up or down relative to the planes of the layers.

The structure of $\mathbf{I I}$ is based upon the $\left[\left(\mathrm{UO}_{2}\right)_{2}\left(\mathrm{SeO}_{4}\right)_{3}\right.$ $\left.\left(\mathrm{H}_{2} \mathrm{O}\right)\right]^{2-}$ layers formed by linkage of $\mathrm{U}$ and Se coordination polyhedra via shared $\mathrm{O}$ atoms (Fig. 4d). The structural layers are parallel to $(-101)$. The negative charge of the layer is compensated by the $\mathrm{K}^{+}$ions arranged in $\left.\left(\mathrm{H}_{2} \mathrm{O}\right)_{4}\right] \cdot 5 \mathrm{H}_{2} \mathrm{O}(\mathbf{I})$
Tab. 3 Selected interatomic distances (d) and angles $(\omega)$ in the structure of $\mathrm{K}_{3}\left(\mathrm{H}_{3} \mathrm{O}\right)\left[\left(\mathrm{UO}_{2}\right)_{4}\left(\mathrm{SeO}_{4}\right)_{6}\right.$

\begin{tabular}{|c|c|c|c|c|}
\hline \multicolumn{3}{|c|}{$\mathrm{d}, \AA$} & \multicolumn{2}{|r|}{$\mathrm{d}, \AA$} \\
\hline $\begin{array}{l}\mathrm{U}(1)-\mathrm{O}(1) \\
\end{array}$ & $1.763(3)$ & $\mathrm{K}(1)-\mathrm{O}(14)$ & $\times 2$ & $2.790(5)$ \\
\hline $\mathrm{U}(1)-\mathrm{O}(2)$ & $1.765(3)$ & $\mathrm{K}(1)-\mathrm{O}(12)$ & $\times 2$ & $2.792(5)$ \\
\hline $\mathrm{U}(1)-\mathrm{O}(16)$ & $2.366(3)$ & $\mathrm{K}(1)-\mathrm{O}(2)$ & $\times 2$ & $2.854(5)$ \\
\hline $\mathrm{U}(1)-\mathrm{O}(4)$ & $2.384(3)$ & $\mathrm{K}(1)-\mathrm{O}(8)$ & $\times 2$ & $2.948(5)$ \\
\hline $\mathrm{U}(1)-\mathrm{O}(6)$ & $2.402(4)$ & $<\mathrm{K} 1-\mathrm{O}>$ & & 2.846 \\
\hline $\mathrm{U}(1)-\mathrm{O}(3)$ & $2.405(3)$ & & & \\
\hline $\mathrm{U}(1)-\mathrm{O}(5)$ & $2.406(3)$ & $\mathrm{K}(2)-\mathrm{H}_{2} \mathrm{O}(24)$ & & $2.730(3)$ \\
\hline$<\mathrm{U}(1)-\mathrm{O}_{U r}>$ & 1.764 & $\mathrm{~K}(2)-\mathrm{H}_{2} \mathrm{O}(26)$ & & $2.750(2)$ \\
\hline \multirow{2}{*}{$<\mathrm{U}(1)-\mathrm{O}_{e q}>$} & 2.333 & $\mathrm{~K}(2)-\mathrm{O}(12)$ & $\times 2$ & $2.806(6)$ \\
\hline & & $\mathrm{K}(2)-\mathrm{H}_{2} \mathrm{O}(21)$ & & $2.899(11)$ \\
\hline $\mathrm{U}(2)-\mathrm{O}(8)$ & $1.761(4)$ & $\mathrm{K}(2)-\mathrm{O}(7)$ & $\times 2$ & $3.024(6)$ \\
\hline $\mathrm{U}(2)-\mathrm{O}(7)$ & $1.767(4)$ & $<\mathrm{K}(2)-\mathrm{O}>$ & & 2.942 \\
\hline $\mathrm{U}(2)-\mathrm{O}(15)$ & $2.358(3)$ & & & \\
\hline $\mathrm{U}(2)-\mathrm{O}(13)$ & $2.384(3)$ & $\mathrm{K}(3)-\mathrm{H}_{2} \mathrm{O}(26)$ & & $2.770(3)$ \\
\hline $\mathrm{U}(2)-\mathrm{O}(11)$ & $2.386(3)$ & $\mathrm{K}(3)-\mathrm{O}(6)$ & $\times 2$ & $2.811(6)$ \\
\hline $\mathrm{U}(2)-\mathrm{H}_{2} \mathrm{O}(9)$ & $2.406(3)$ & $\mathrm{K}(3)-\mathrm{H}_{2} \mathrm{O}(22)$ & & $2.813(12)$ \\
\hline $\mathrm{U}(2)-\mathrm{H}_{2} \mathrm{O}(10)$ & $2.412(4)$ & $\mathrm{K}(3)-\mathrm{O}(1)$ & $\times 2$ & $2.980(7)$ \\
\hline$<\mathrm{U}(2)-\mathrm{O}_{U r}>$ & 1.764 & $\mathrm{~K}(3)-\mathrm{H}_{2} \mathrm{O}(24)$ & & $3.060(2)$ \\
\hline$<\mathrm{U}(2)-\mathrm{O}_{e q}>$ & 2.389 & $<\mathrm{K}(3)-\mathrm{O}>$ & & 2.964 \\
\hline $\mathrm{Se}(1)-\mathrm{O}(12)$ & $1.613(4)$ & $\mathrm{K}(4)-\mathrm{O}(17)$ & $\times 2$ & $2.847(8)$ \\
\hline Se(1)-O(6) & $1.638(3)$ & $\mathrm{K}(4)-\mathrm{H}_{2} \mathrm{O}(25)$ & & $2.920(2)$ \\
\hline $\mathrm{Se}(1)-\mathrm{O}(11)$ & $1.639(3)$ & $\mathrm{K}(4)-\mathrm{H}_{2} \mathrm{O}(23)$ & & $2.990(3)$ \\
\hline $\mathrm{Se}(1)-\mathrm{O}(13)$ & $1.645(3)$ & $\mathrm{K}(4)-\mathrm{O}(16)$ & $\times 2$ & $3.160(6)$ \\
\hline$<\mathrm{Se}(1)-\mathrm{O}>$ & 1.634 & $<\mathrm{K}(4)-\mathrm{O}>$ & & 2.901 \\
\hline $\mathrm{Se}(2)-\mathrm{O}(14)$ & $1.621(4)$ & & & \\
\hline $\mathrm{Se}(2)-\mathrm{O}(3)$ & $1.635(3)$ & Angle & & $\omega,{ }^{\circ}$ \\
\hline $\mathrm{Se}(2)-\mathrm{O}(5)$ & $1.648(3)$ & $\mathrm{U}(1)-\mathrm{O}(6)-\mathrm{S}$ & & $135.4(3)$ \\
\hline $\mathrm{Se}(2)-\mathrm{O}(15)$ & $1.650(3)$ & $\mathrm{U}(1)-\mathrm{O}(5)-\mathrm{S}$ & & 133.1(3) \\
\hline \multirow[t]{2}{*}{$<\mathrm{Se}(2)-\mathrm{O}>$} & 1.638 & $\mathrm{U}(1)-\mathrm{O}(3)-\mathrm{S}$ & & $133.8(3)$ \\
\hline & & $U(1)-O(16)-$ & e(3) & $135.7(3)$ \\
\hline $\mathrm{Se}(3)-\mathrm{O}(17)$ & $1.613(4)$ & $\mathrm{U}(1)-\mathrm{O}(4)-\mathrm{S}$ & & $139.6(3)$ \\
\hline $\mathrm{Se}(3)-\mathrm{O}(18)$ & $1.639(4)$ & $\mathrm{U}(2)-\mathrm{O}(13)-$ & e(1) & $130.6(3)$ \\
\hline $\mathrm{Se}(3)-(\mathrm{O} 4)$ & $1.641(3)$ & $\mathrm{U}(2)-\mathrm{O}(11)-\mathrm{S}$ & (1) & 132.3(3) \\
\hline $\mathrm{Se}(3)-\mathrm{O}(16)$ & $1.646(4)$ & $\mathrm{U}(2)-\mathrm{O}(15)-\mathrm{S}$ & (2) & 135.7(3) \\
\hline$<\mathrm{Se}(3)-\mathrm{O}>$ & 1.635 & & & \\
\hline
\end{tabular}

between the 2-D uranyl selenate units. Along with the potassium atoms, the interlayer contains four symmetrically independent $\mathrm{H}_{2} \mathrm{O}$ molecules and disordered $\mathrm{NO}_{3}$ groups.

Analysis of the topology of the uranyl selenate layers using graphs (Krivovichev 2004, 2008) indicates that the topology of the 2-D layers of the $c c 2-2: 3-12$ type (linkage of 4-membered rings and 8 -membered rings with the latter ones forming rows along [010] Fig. 4e-f) and is identical to that found in uranyl sulphate $\left[\mathrm{C}_{8} \mathrm{H}_{26} \mathrm{~N}_{4}\right]_{0.5}\left[\left(\mathrm{UO}_{2}\right)_{2}\left(\mathrm{SO}_{4}\right)_{3}\left(\mathrm{H}_{2} \mathrm{O}\right)\right]$ (Doran et al. 2004). However, the layer of this type had not been observed previously in uranyl selenates.

In the crystal structure of $\mathbf{I}$ there are four symmetrically independent $\mathrm{K}$ atoms that occupy special positions 


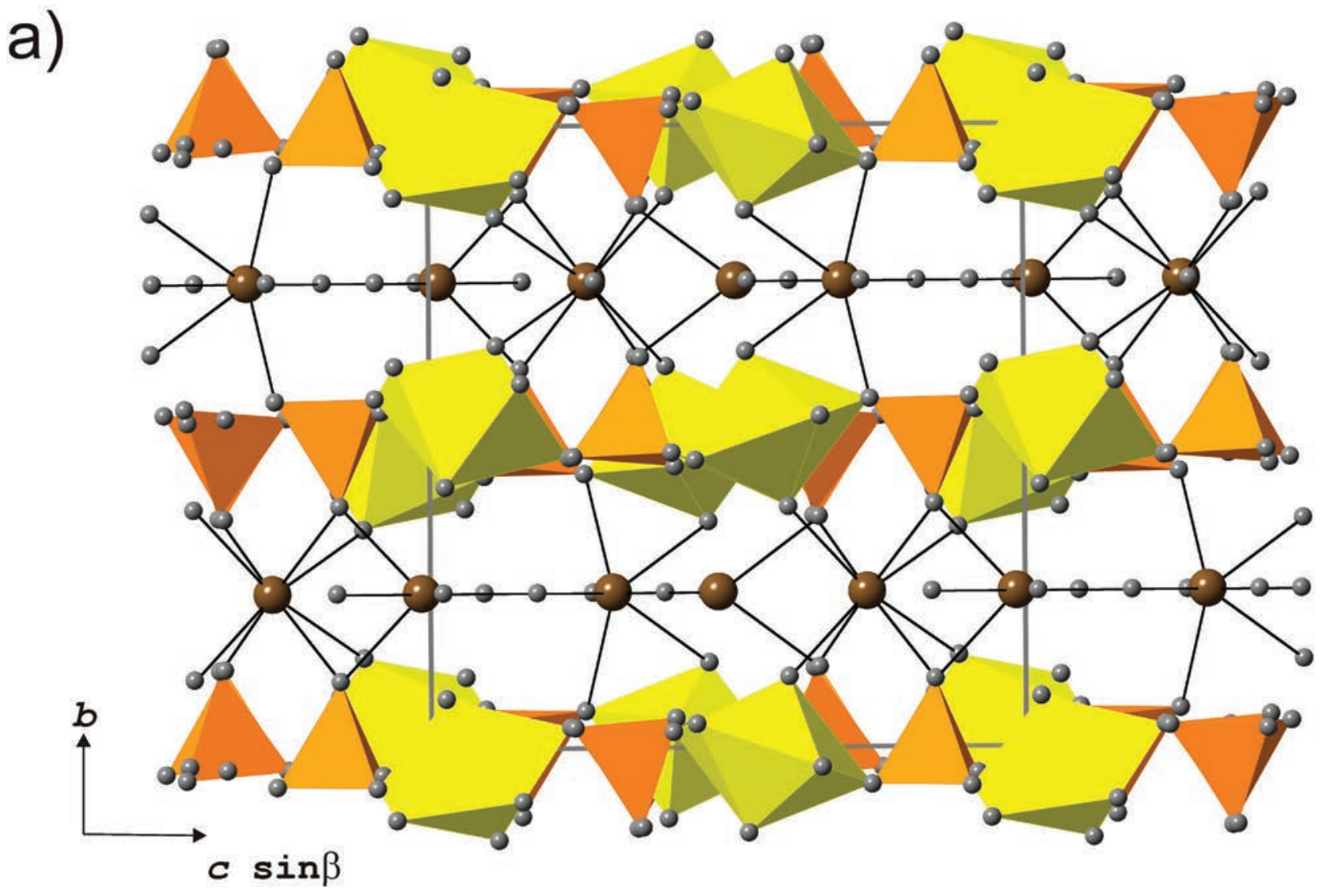

b)
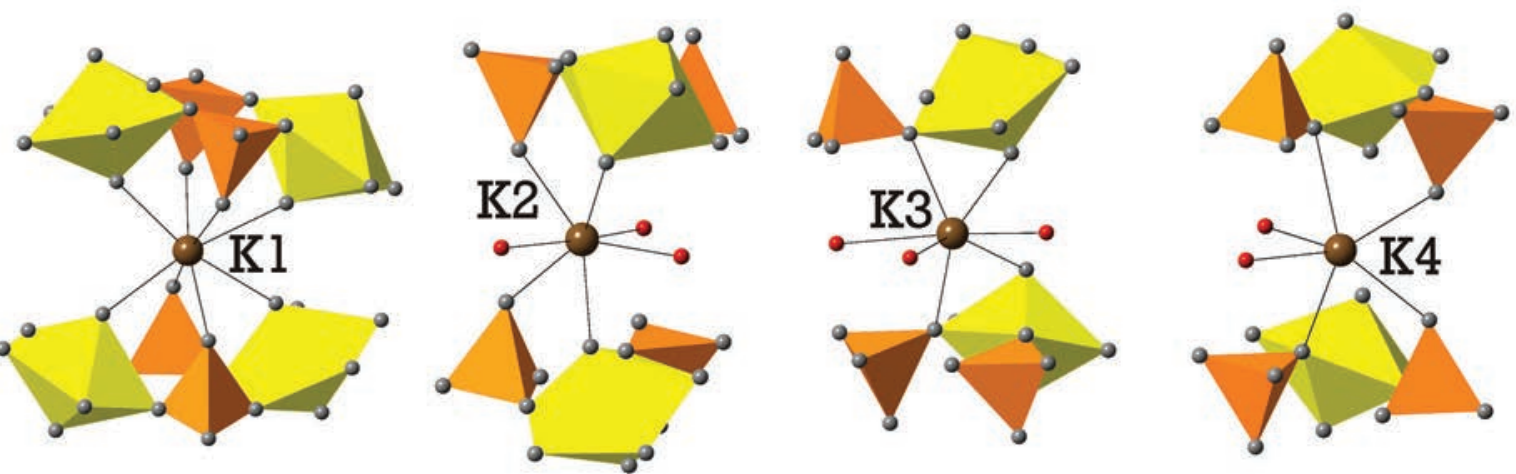

Fig. 2 Crystal structure of $\mathbf{I}(\mathbf{a})$ and coordination of $\mathrm{K}$ atoms in the structure of $\mathbf{I}(\mathbf{b})$. Legend: $\mathrm{U}$ polyhedra $=$ yellow, Se tetrahedra $=$ orange, $\mathrm{K}$ atoms $=$ brown, $\mathrm{O}$ atoms $=$ grey $\left[\mathrm{in}(\mathbf{b}) \mathrm{H}_{2} \mathrm{O}\right.$ groups are shown as red spheres].

on the mirror plane $m$. These $\mathrm{K}^{+}$ions are surrounded by the $\mathrm{O}$ atoms belonging to the $\mathrm{U}-$ Se layers and also to the $\mathrm{H}_{2} \mathrm{O}$ molecules in the interlayer. The $\mathrm{K} 1$ atom forms eight bonds to $\mathrm{O}$ atoms equally distributed between the two adjacent layers $(\mathrm{K}(1)-\mathrm{O}$ bond lengths vary in the range of 2.790(5)-2.948(5) A. Among the eight bonds, four are to the terminal $\mathrm{O}$ atoms of the selenate tetrahedra, whereas four others are to the $\mathrm{O}$ atoms of uranyl ions. The $\mathrm{K}(2)$ atom forms seven bonds $(\mathrm{K}(2)-\mathrm{O}=2.730(3)-3.024(6) \AA)$ with four bonds to the terminal $\mathrm{O}$ atoms of the selenate tetrahedra and $\mathrm{O}_{U r}$ atoms from adjacent layers and three bonds to the interlayer $\mathrm{H}_{2} \mathrm{O}$ molecules. The $\mathrm{K}(3)$ atom forms seven bonds $(\mathrm{K}(3)-\mathrm{O}=2.770(3)-3.060(2) \AA)$ : four bonds to $\mathrm{O}$ atoms from adjacent layers (two to the uranyl

Fig. 3 Crystal structure of II (a) and coordination of $\mathrm{K}$ atoms in the structure of II (b). Legend: U polyhedra $=$ yellow, Se tetrahedra $=$ orange, $\mathrm{NO}_{3}$ groups = light-blue, $\mathrm{K}$ atoms = brown, $\mathrm{O}$ atoms = grey [in (b) $\mathrm{H}_{2} \mathrm{O}$ groups are shown as red spheres and $\mathrm{NO}_{3}$ groups in a stick-bond mode]. Hydrogen atoms are omitted for clarity. 

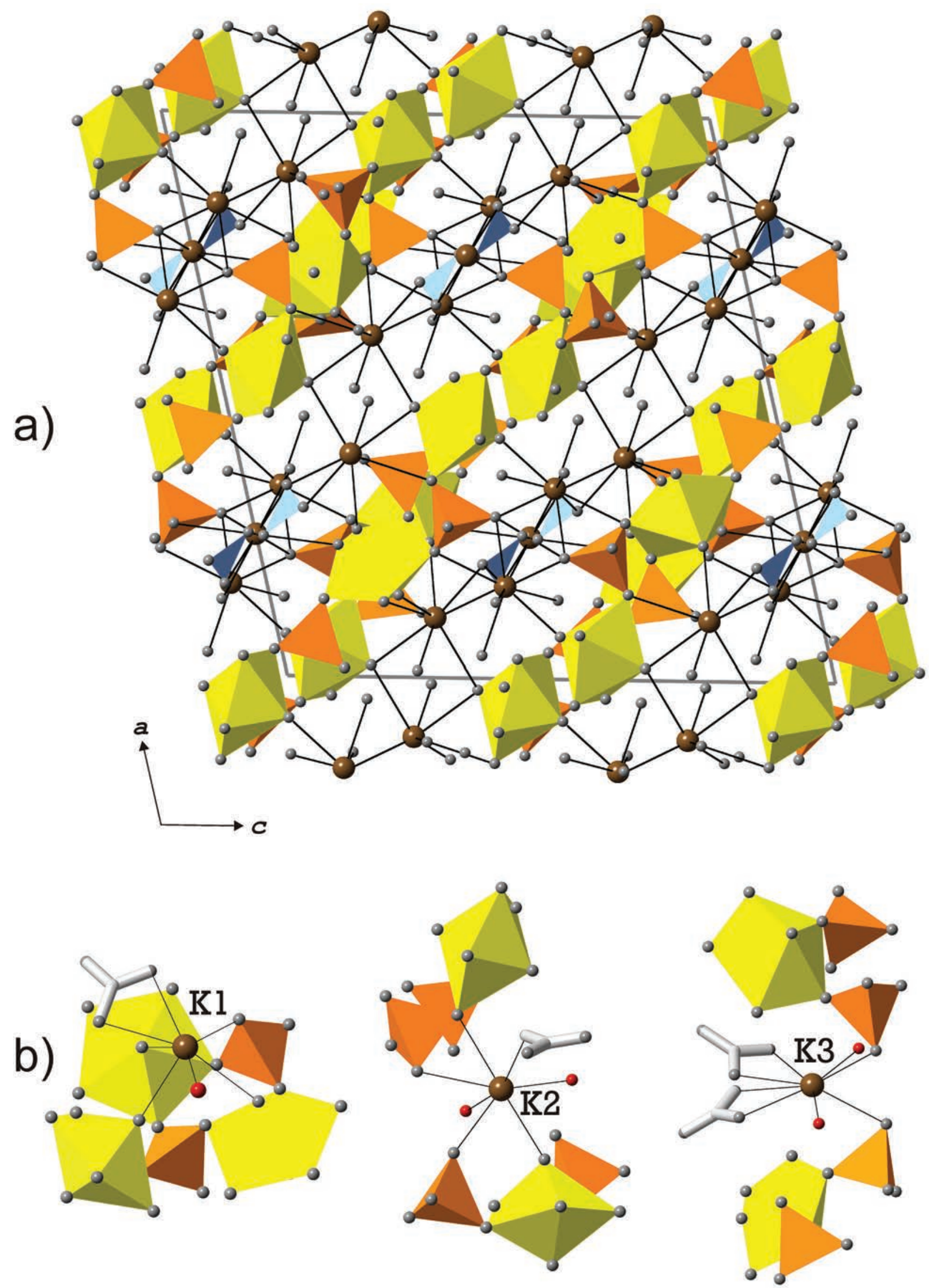
Tab. 4 Coordinates and displacement parameters $\left(\AA^{2}\right)$ of atoms forming the structure of $\mathrm{K}_{2.5}\left(\mathrm{NO}_{3}\right)_{0.5}\left[\left(\mathrm{UO}_{2}\right)_{2}\left(\mathrm{SeO}_{4}\right)_{3}\left(\mathrm{H}_{2} \mathrm{O}\right)\right] \cdot 4 \mathrm{H}_{2} \mathrm{O}(\mathbf{I I})$

\begin{tabular}{|c|c|c|c|c|}
\hline Atom & $\mathrm{x} / \mathrm{a}$ & $\mathrm{y} / \mathrm{b}$ & $\mathrm{z} / \mathrm{C}$ & $U_{\text {eq }}$ \\
\hline $\mathrm{U}(1)$ & $0.788786(8)$ & $0.339121(14)$ & $0.297341(8)$ & $0.01423(4)$ \\
\hline $\mathrm{U}(2)$ & $0.585894(9)$ & $0.252956(15)$ & $0.047975(8)$ & $0.01623(4)$ \\
\hline $\operatorname{Se}(1)$ & $0.86684(2)$ & $0.66241(4)$ & $0.28249(2)$ & $0.01491(9)$ \\
\hline $\operatorname{Se}(2)$ & $0.70933(2)$ & $0.49973(4)$ & $0.14020(2)$ & $0.01499(9)$ \\
\hline $\operatorname{Se}(3)$ & $0.56264(2)$ & $-0.10793(4)$ & $0.06678(2)$ & $0.01800(9)$ \\
\hline $\mathrm{K}(1)$ & $0.70613(8)$ & $0.66516(12)$ & $0.39448(7)$ & $0.0408(3)$ \\
\hline $\mathrm{K}(3)$ & 0 & $0.45833(18)$ & $1 / 4$ & $0.0552(6)$ \\
\hline $\mathrm{O}(1)$ & $0.8135(2)$ & $0.2426(3)$ & $0.23893(17)$ & $0.0243(7)$ \\
\hline $\mathrm{O}(2)$ & $0.7066(2)$ & $0.6565(3)$ & $0.13271(17)$ & $0.0232(7)$ \\
\hline $\mathrm{O}(3)$ & $0.76367(19)$ & $0.4374(3)$ & $0.35480(16)$ & $0.0218(7)$ \\
\hline $\mathrm{O}(4)$ & $0.81998(19)$ & $0.7434(3)$ & $0.22272(17)$ & $0.0225(7)$ \\
\hline $\mathrm{O}(5)$ & $0.84342(18)$ & $0.6982(3)$ & $0.34893(16)$ & $0.0204(7)$ \\
\hline $\mathrm{O}(7)$ & $0.51462(19)$ & $0.3064(3)$ & $0.07445(19)$ & $0.0261(8)$ \\
\hline $\mathrm{O}(8)$ & $0.65774(19)$ & $0.2036(4)$ & $0.02079(18)$ & $0.0281(8)$ \\
\hline $\mathrm{O}(9)$ & $0.85402(19)$ & $0.5088(3)$ & $0.26689(18)$ & $0.0247(8)$ \\
\hline $\mathrm{O}(10)$ & $0.71335(18)$ & $0.4619(3)$ & $0.21564(16)$ & $0.0226(7)$ \\
\hline $\mathrm{O}(11)$ & $0.5983(2)$ & $-0.1718(3)$ & $0.13638(19)$ & $0.0286(8)$ \\
\hline $\mathrm{O}(12)$ & $0.48700(19)$ & $-0.1743(3)$ & $0.04643(17)$ & $0.0257(8)$ \\
\hline $\mathrm{O}(13)$ & $0.63656(18)$ & $0.4472(3)$ & $0.09601(17)$ & $0.0236(7)$ \\
\hline $\mathrm{O}(14)$ & $0.5512(2)$ & $0.0464(3)$ & $0.07707(18)$ & $0.0268(8)$ \\
\hline $\mathrm{O}(15)$ & $0.6076(2)$ & $-0.1294(4)$ & $0.01469(19)$ & $0.0330(9)$ \\
\hline $\mathrm{O}(16)$ & $0.94523(18)$ & $0.6961(4)$ & $0.28594(19)$ & $0.0267(8)$ \\
\hline $\mathrm{O}(17)$ & $0.5727(3)$ & $0.4170(4)$ & $-0.0337(2)$ & $0.0450(12)$ \\
\hline $\mathrm{H}(17 \mathrm{~A})$ & $0.558(4)$ & $0.505(4)$ & $-0.025(4)$ & 0.067 \\
\hline H(17B) & $0.539(3)$ & $0.408(7)$ & $-0.0759(19)$ & 0.067 \\
\hline $\mathrm{H}(18 \mathrm{~A})$ & $0.680(2)$ & $0.656(6)$ & $-0.049(4)$ & 0.051 \\
\hline $\mathrm{H}(18 \mathrm{~B})$ & $0.628(4)$ & $0.714(4)$ & $-0.015(3)$ & 0.051 \\
\hline $\mathrm{O}(19)$ & $0.7599(2)$ & $0.5295(5)$ & $-0.0115(2)$ & $0.0387(10)$ \\
\hline H(19A) & $0.760(4)$ & $0.465(6)$ & $0.022(3)$ & 0.058 \\
\hline H(19B) & $0.798(3)$ & $0.557(7)$ & $-0.030(4)$ & 0.058 \\
\hline $\mathrm{O}(20)$ & $0.4111(3)$ & $0.0504(6)$ & $0.1341(3)$ & $0.0612(15)$ \\
\hline $\mathrm{H}(20 \mathrm{~A})$ & $0.434(5)$ & $0.028(9)$ & $0.099(3)$ & 0.092 \\
\hline $\mathrm{H}(20 \mathrm{~B})$ & $0.399(5)$ & $-0.043(3)$ & $0.129(5)$ & 0.092 \\
\hline $\mathrm{O}(21)$ & $0.4741(4)$ & $0.4422(7)$ & $-0.1395(3)$ & $0.078(2)$ \\
\hline $\mathrm{H}(21 \mathrm{~A})$ & $0.513(2)$ & $0.434(11)$ & $-0.163(2)$ & 0.118 \\
\hline $\mathrm{H}(21 \mathrm{~B})$ & $0.438(2)$ & $0.435(10)$ & $-0.181(2)$ & 0.118 \\
\hline $\mathrm{N}(1)^{*}$ & $0.4368(6)$ & $0.6592(10)$ & $0.2017(6)$ & $0.0443(13)$ \\
\hline $\mathrm{O}(22)^{*}$ & $0.4024(5)$ & $0.5477(8)$ & $0.2014(5)$ & $0.0443(13)$ \\
\hline $\mathrm{O}(23)^{*}$ & $0.4867(5)$ & $0.6910(7)$ & $0.2527(7)$ & $0.0443(13)$ \\
\hline $\mathrm{O}(24)^{*}$ & $0.4233(5)$ & $0.7589(8)$ & $0.1619(5)$ & $0.0443(13)$ \\
\hline
\end{tabular}

* site-occupation factor is 0.5 .

$\mathrm{O}$ atoms and two to the bridging $\mathrm{O}$ atoms between the $\mathrm{U}$ and Se atoms) and three more bonds to $\mathrm{H}_{2} \mathrm{O}$ molecules in the interlayer. The $\mathrm{K}(4)$ atom forms six bonds $(\mathrm{K}(4)-\mathrm{O}$ $=2.847(8)-3.160(6) \AA)$ : two to the terminal $\mathrm{O}$ atoms of the selenate tetrahedra, two to the bridging $\mathrm{O}$ atoms and two to the $\mathrm{H}_{2} \mathrm{O}$ molecules in the interlayer.

In the crystal structure of II there are three symmetrically independent potassium atoms (Fig. 3b). The $\mathrm{K}(1)$ atom forms three bonds to $\mathrm{O}_{U r}$ atoms and one bond to terminal $\mathrm{O}$ atom of $\left[\mathrm{SeO}_{4}\right]$ tetrahedra from the same layer, one bond $(\mathrm{K}(1)-\mathrm{O}(19)$ to water molecule and two bonds to the $\mathrm{O}$ atoms of the same nitrate group (K(1)$\mathrm{O}(22), \mathrm{K}(1)-\mathrm{O}(24))$. The $\mathrm{K}(1)-\mathrm{O}$ bond lengths fall in the range of 2.799(10)-2.959(4) $\AA$. The $\mathrm{K}(2)$ atom forms seven bonds $(\mathrm{K}(2)-\mathrm{O}=2.707(8)-2.997(4) \AA)$ : two to the terminal $\mathrm{O}$ atoms of the selenate groups from adjacent layers, one to bridging $\mathrm{O}$ atom, one to $\mathrm{O}_{U r}$ atom, two to the interlayer water molecules and one to $\mathrm{O}$ atoms of 
the $\mathrm{NO}_{3}$ group. The $\mathrm{K}(3)$ atom forms eight bonds to $\mathrm{O}$ atoms $(2.789(8)-2.984(9) \AA)$ and is most isolated from the layers. It has two bonds with terminal $\mathrm{O}$ atoms of selenate tetrahedra and six other contacts are concentrated within the interlayer space: two bonds with $\mathrm{H}_{2} \mathrm{O}$ molecules and four bonds with $\mathrm{O}$ atoms from two symmetrically equivalent nitrate groups.

It is worth noting that the $\mathrm{K}(1)$ atom in the structure of I is arranged in front of the $\mathrm{U}(1)-\mathrm{Se}(2)-\mathrm{U}(2)-\mathrm{Se}(1)$ fourmembered ring, forming bonds exclusively with the apical $\mathrm{O}$ atoms of the selenate tetrahedra and uranyl ions (Fig. 2b). This results in the observed local curvature of the U-Se-U-Se units (the angle between the equatorial planes of the uranyl bipyramids is equal to $132.2^{\circ}$ ). The $\mathrm{K}(4)$ atom is also arranged in front of the U(1)-Se(3)-U1Se(3) four-membered ring, but, in this case, the equatorial planes of the $\mathrm{U}(1)$ bipyramids are parallel. The $\mathrm{K}(2)$ and $\mathrm{K}(3)$ atoms are shifted from the central position closer to uranyl polyhedron. Therefore, as shown also by the above-described coordination features, there is no exact effect of curvature induction for these positions.
Tab. 5 Selected interatomic distances $(d)$ and angles $(\omega)$ in the structure of $\mathrm{K}_{2.5}\left(\mathrm{NO}_{3}\right)_{0.5}\left[\left(\mathrm{UO}_{2}\right)_{2}\right.$ $\left.\left(\mathrm{SeO}_{4}\right)_{3}\left(\mathrm{H}_{2} \mathrm{O}\right)\right] \cdot 4 \mathrm{H}_{2} \mathrm{O}(\mathrm{II})$

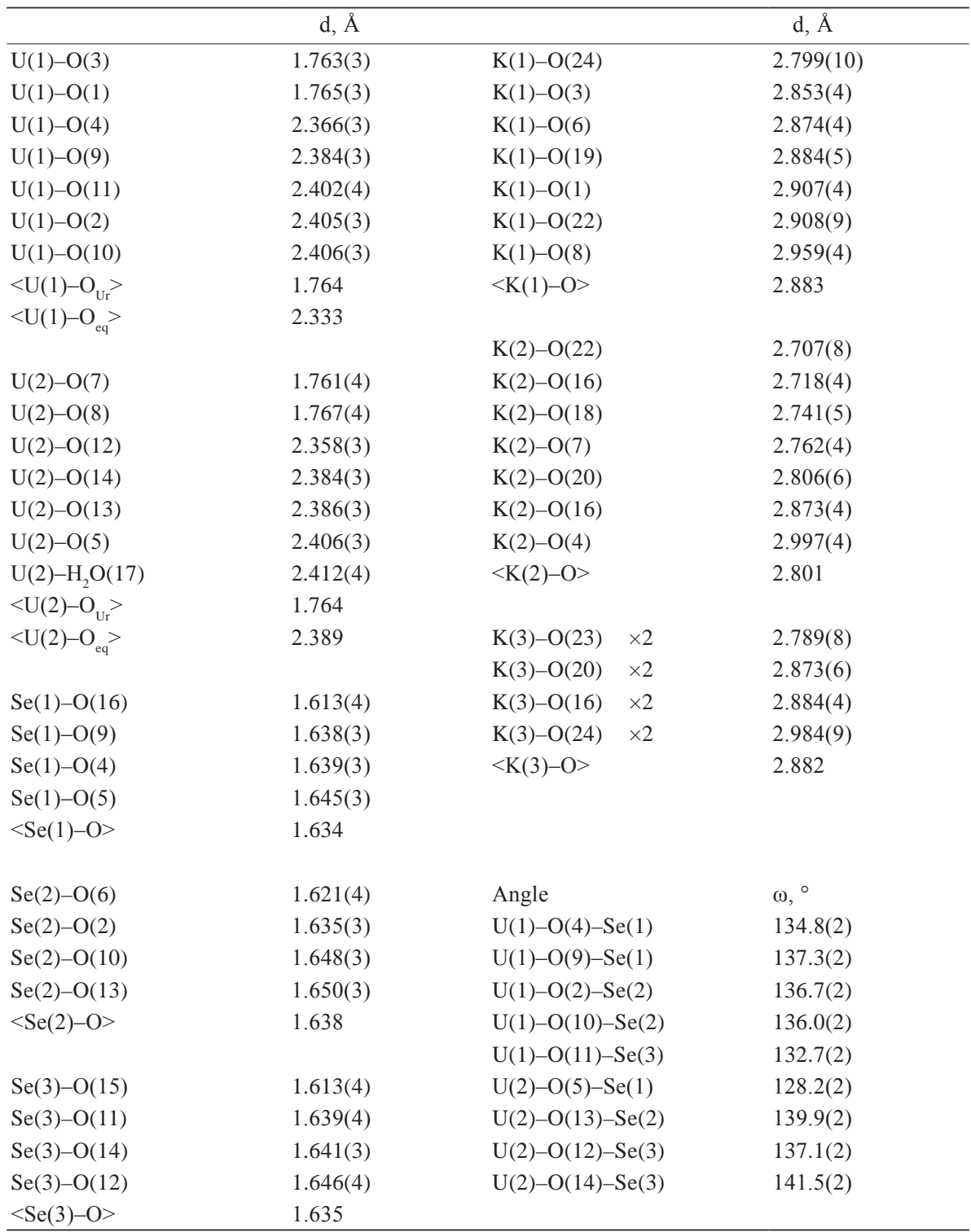

\section{Concluding remarks}

As it was suggested by Gurzhiy et al. (2011), K atoms have specific ionic properties (Cartledge ionic potential) suitable for inducing the curvature of the uranyl selenate complexes in aqueous solutions. Latter, Gurzhiy et al. (2012) demonstrated that not only the $\mathrm{pH}$ of the solution (presence of the protonated water complexes in the structure) could control the modification of layers, but also the $\mathrm{K} /\left(\mathrm{H}_{2} \mathrm{O}+\mathrm{H}_{3} \mathrm{O}+\mathrm{H}_{5} \mathrm{O}_{2}+\ldots\right)$ ratio should be taken into account. It was also shown that if such ratio is equal or less than 1:2, the uranyl selenate layers are flat. The structures reported herein confirm these empirical observations. Interlayer space of the structure of I contains both
$\mathrm{H}_{2} \mathrm{O}$ molecules and $\mathrm{H}_{3} \mathrm{O}^{+}$ions along with $\mathrm{K}^{+}$cations; the $\mathrm{K} /\left(\mathrm{H}_{2} \mathrm{O}+\mathrm{H}_{3} \mathrm{O}+\mathrm{H}_{5} \mathrm{O}_{2}+\ldots\right)$ ratio equals to $1: 2$. The same ratio in the structure of $\mathbf{I I}$ is $5: 8$, that is, more than $1: 2$, but no global layer curvature is observed. However, these layers contain significantly distorted regions with coordination environment of the $\mathrm{K}(1)$ atom very similar to those observed in structures with uranyl selenate nanotubules. We are inclined to ascribe the absence of the layer curvature to the presence of nitrate groups arranged in between the uranyl selenate layers and playing a considerable role in coordination of the $\mathrm{K}^{+}$ions. In addition, the position of nitrate anions inhibits the curvature electrostatically: apparently, the parallel orientation of the $\mathrm{NO}_{3}$ groups favours repulsion between them and the layers, thus 

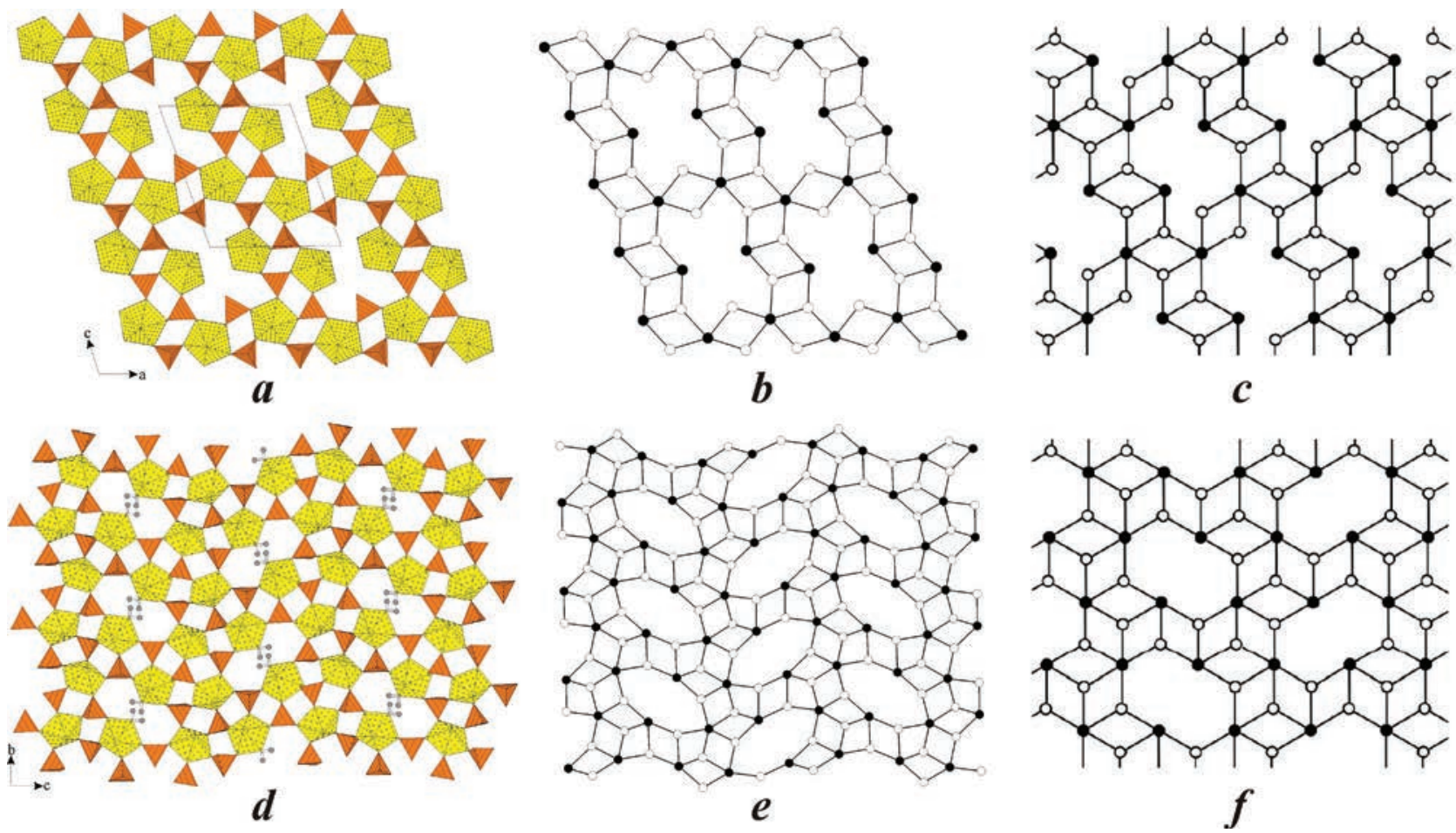

Fig. 4 Uranyl selenate layers in the structures of I (a) and II (d) and its real (b and e, respectively) and idealized (c and f, respectively) graphical representations.

supporting the flat architecture of uranyl selenate layers. It is interesting that the ratio $\mathrm{K}: \mathrm{NO}_{3}$ for the structure of $\mathrm{K}_{25}\left(\mathrm{NO}_{3}\right)_{0,5}\left[\left(\mathrm{UO}_{2}\right)_{2}\left(\mathrm{SeO}_{4}\right)_{3}\left(\mathrm{H}_{2} \mathrm{O}\right)\right] \cdot 4 \mathrm{H}_{2} \mathrm{O}$ (II) is $5: 1$, i.e. the same as for the structure of $\mathrm{K}_{5}\left[\left(\mathrm{UO}_{2}\right)_{3}\left(\mathrm{SeO}_{4}\right)_{5}\right]\left(\mathrm{NO}_{3}\right)$ $\left(\mathrm{H}_{2} \mathrm{O}\right)_{3.5}$, which is based upon uranyl selenate nanotubules. However, the latter compound contains noticeably less water $\left(\mathrm{K}: \mathrm{H}_{2} \mathrm{O}=1: 0.7\right)$ compared to that observed in II $\left(\mathrm{K}: \mathrm{H}_{2} \mathrm{O}=1: 1.6\right)$, which may be considered a reason for the formation of layered instead of nanotubular structure. It is very probable that the relative amount of $\mathrm{H}_{2} \mathrm{O}$ is of critical importance for the formation of particular structural topology. The synthesis of $\mathrm{K}_{5}\left[\left(\mathrm{UO}_{2}\right)_{3}\left(\mathrm{SeO}_{4}\right)_{5}\right]\left(\mathrm{NO}_{3}\right)$ $\left(\mathrm{H}_{2} \mathrm{O}\right)_{3.5}$ with the nanotubule-based structure was done at slightly elevated temperature $\left(60^{\circ} \mathrm{C}\right)$, which decreased the water amount in the structure.

Acknowledgements. We thank S. Mills and an anonymous referee for useful suggestions and language polishing. This work was supported by St. Petersburg State University and RFBR (grant 12-05-31344 to VVG). XRD studies have been performed at the X-ray Diffraction Centre of St. Petersburg State University.

Electronic supplementary material. Supplementary crystallographic data for this paper are available online at the Journal web site (http://dx.doi.org/10.3190/ jgeosci.165).

\section{References}

Alekseev EV, Krivovichev SV, Depmeier W (2008) A crown ether as template for microporous and nanostructured uranium compounds. Angew Chem Int Ed 47: $549-551$

BuRNs PC (2005) $\mathrm{U}^{6+}$ minerals and inorganic compounds: insights into an expanded structural hierarchy of crystal structures. Canad Mineral 43: 1839-1894

Burns PC, Ewing RC, Hawthorne FC (1997) The crystal chemistry of hexavalent uranium: polyhedral geometries, bond-valence parameters, and polymerization of polyhedra. Canad Mineral 35: 1551-1570

Charykova MV, Krivovichev VG, Depmeier W (2010) Thermodynamics of arsenates, selenites, and sulfates in the oxidation zone of sulfide ores: I. Thermodynamic constants at ambient conditions. Geol Ore Depos 52: 689-700

Charykova MV, Krivovichev VG, Yakovenko OS, Semenova VV, Semenov KN, Depmeier W (2012) Thermodynamics of arsenates, selenites, and sulfates in the oxidation zone of sulfide ores: VI. Solubility of synthetic analogs of ahlfeldite and cobaltomenite at $25^{\circ} \mathrm{C}$. Geol Ore Depos 54: 638-646

ČEJKA J (1999) Infrared spectroscopy and thermal analysis of the uranyl minerals. In: BuRns PC, Finch R (eds) Uranium: Mineralogy, Geochemistry and the Environment. Mineralogical Society of America and Geochemical 
Society Reviews in Mineralogy and Geochemistry 38: pp 521-620

Dolomanov OV, Bourhis LJ, Gildea RJ, Howard JAK, Puschmann H (2009) OLEX2: a complete structure solution, refinement and analysis program. J Appl Cryst 42: 339-341

Doran MB, Norquist AJ, Stuart SL, O’Hare D (2004) $\left(\mathrm{C}_{8} \mathrm{H}_{26} \mathrm{~N}_{4}\right)_{0.5}\left[\left(\mathrm{UO}_{2}\right)_{2}\left(\mathrm{SO}_{4}\right)_{3}\left(\mathrm{H}_{2} \mathrm{O}\right)\right] \cdot 2 \mathrm{H}_{2} \mathrm{O}$, an organically templated uranyl sulfate with a novel layer type. Acta Cryst E60: m996-m998

Finch RJ, Buck EC, Finn PA, Bates JK (1999) Oxidative corrosion of spent $\mathrm{UO}_{2}$ fuel in vapour and dripping groundwater at $90^{\circ} \mathrm{C}$. In: Murakami T, EwIng RC (eds) Scientific Basis for Nuclear Waste Management. XXII ${ }^{\text {th }}$ Materials Research Society Symposium Proceeding. Materials Research Society, Warrendale, PA, Vol 556, pp 431-438

Gurzhiy VV, Bessonov AA, Krivovichev SV, Tananaev IG, Armbruster T, Myasoedov BF (2009) Crystal chemistry of selenates with mineral-like structures: VIII. Butlerite chains in the structure of $\mathrm{K}\left(\mathrm{UO}_{2}\right)\left(\mathrm{SeO}_{4}\right)(\mathrm{OH})\left(\mathrm{H}_{2} \mathrm{O}\right)$. Geol Ore Depos 51: 833-837

Gurzhiy VV, Tyumentseva OS, Krivovichev SV, TanaNAEv IG, Myasoedov BF (2011) Synthesis and structural study of new potassium uranyl selenates $\mathrm{K}_{2}\left(\mathrm{H}_{5} \mathrm{O}_{2}\right)$ $\left(\mathrm{H}_{3} \mathrm{O}\right)\left[\left(\mathrm{UO}_{2}\right)_{2}\left(\mathrm{SeO}_{4}\right)_{4}\left(\mathrm{H}_{2} \mathrm{O}\right)_{2}\right]\left(\mathrm{H}_{2} \mathrm{O}\right)_{4}$ and $\mathrm{K}_{3}\left(\mathrm{H}_{3} \mathrm{O}\right)$ $\left[\left(\mathrm{UO}_{2}\right)_{2}\left(\mathrm{SeO}_{4}\right)_{4}\left(\mathrm{H}_{2} \mathrm{O}\right)_{2}\right]\left(\mathrm{H}_{2} \mathrm{O}\right)_{5}$. Radiochem 53: 569-575

Gurzhiy VV, Tyumentseva OS, Krivovichev SV, TanaNAEv IG, Myasoedov BF (2012) Synthesis and structural studies of a new potassium uranyl selenate $\mathrm{K}\left(\mathrm{H}_{5} \mathrm{O}_{2}\right)$ $\left[\left(\mathrm{UO}_{2}\right)_{2}\left(\mathrm{SeO}_{4}\right)_{3}\left(\mathrm{H}_{2} \mathrm{O}\right)\right]$ with strongly deformed layers. Radiochem 54: 43-47

KRIVOVICHEV SV (2004) Combinatorial topology of salts of inorganic oxoacids: zero-, one- and two dimensional units with corner-sharing between coordination polyhedra. Crystallography Rev 10: 185-232

Krivovichev SV (2008) Structural Crystallography of Inorganic Oxysalts. Oxford University Press, Oxford, pp 1-308

KrIVOVICHeV SV (2010) Actinyl compounds with hexavalent elements ( $\mathrm{S}, \mathrm{Cr}, \mathrm{Se}, \mathrm{Mo}$ ) - structural diversity, nanoscale chemistry, and cellular automata modeling. Eur J Inorg Chem 2010: 2594-2603

Krivovichev SV (2013) Crystal chemistry of uranium oxides and minerals. In: ReEdiJK J, Poeppelmeier K (eds) Comprehensive Inorganic Chemistry II, Vol 2. Elsevier, Amsterdam, pp 611-640

Krivovichev SV, Kahlenberg V (2005a) Crystal structure of $\left(\mathrm{H}_{3} \mathrm{O}\right)_{2}\left[\left(\mathrm{UO}_{2}\right)_{2}\left(\mathrm{SeO}_{4}\right)_{3}\left(\mathrm{H}_{2} \mathrm{O}\right)_{2}\right]\left(\mathrm{H}_{2} \mathrm{O}\right)_{3.5}$. Radiochem 47: 452-455
Krivovichev SV, Kahlenberg V (2005b) Structural diversity of sheets in rubidium uranyl oxoselenates: synthesis and crystal structures of $\mathrm{Rb}_{2}\left[\left(\mathrm{UO}_{2}\right)\right.$ $\left.\left(\mathrm{SeO}_{4}\right)_{2}\left(\mathrm{H}_{2} \mathrm{O}\right)\right]\left(\mathrm{H}_{2} \mathrm{O}\right), \mathrm{Rb}_{2}\left[\left(\mathrm{UO}_{2}\right)_{2}\left(\mathrm{SeO}_{4}\right)_{3}\left(\mathrm{H}_{2} \mathrm{O}\right)_{2}\right]\left(\mathrm{H}_{2} \mathrm{O}\right)_{4}$, $\mathrm{Rb}_{4}\left[\left(\mathrm{UO}_{2}\right)_{3}\left(\mathrm{SeO}_{4}\right)_{5}\left(\mathrm{H}_{2} \mathrm{O}\right)\right]$. Z Anorg Allg Chem 631: 739-744

Krivovichev SV, Plášil J (2013) Mineralogy and crystallography of uranium. In: Burns PC, Sigmon GE (eds) Uranium: Cradle to Grave. Mineralogical Association of Canada Short Courses 43: pp 15-120

Krivovichev SV, Kahlenberg V, Kaindl R, Mersdorf E, Tananaev IG, Myasoedov BF (2005a) Nanoscale tubules in uranyl selenates. Angew Chem Int Ed 44: 1134-1136

Krivovichev SV, Kahlenberg V, Tananaev IG, Kaindl R, Mersdorf E, Myasoedov BF (2005b) Highly porous uranyl selenate nanotubules. J Am Chem Soc 127: 1072-1073

Krivovichev SV, Burns PC, TAnanaev IG (2007) Structural Chemistry of Inorganic Actinide Compounds. Elsevier, Amsterdam, pp 1-494

Krivovichev SV, Gurzhiy VV, Tananaev IG, Myasoedov BF (2009) Uranyl selenates with organic templates: principles of structure and characteristics of self-organization. Rus J Gen Chem 79: 2723--730

Krivovichev VG, Charykova MV, Yakovenko OS, DepMEIER W (2011a) Thermodynamics of arsenates, selenites, and sulfates in the oxidation zone of sulfide ores: IV. $\mathrm{Eh}-\mathrm{pH}$ diagrams of the $\mathrm{Me}-\mathrm{Se}-\mathrm{H}_{2} \mathrm{O}$ systems $(\mathrm{Me}=\mathrm{Co}$, $\mathrm{Ni}, \mathrm{Fe}, \mathrm{Cu}, \mathrm{Zn}, \mathrm{Pb})$ at $25^{\circ} \mathrm{C}$. Geol Ore Depos 53: 514-527

Krivovichev SV, Gurzhiy VV, Tananaev IG, Myasoedov BF (2011b) Nanoscale chemistry of uranyl selenates. In: Kalmykov SN, Denecke MA (eds) Actinide Nanoparticle Research. Springer-Verlag, Berlin, pp 247-275

Krivovichev VG, Tarasevich DA, Charykova MV, Britvin SN, SiIdra OI, Depmeier W (2012) Thermodynamics of arsenates, selenites, and sulfates in the oxidation zone of sulfide ores: V. Chalcomenite and its synthetic analog properties and formation conditions. Geol Ore Depos 54: 498-502

Ling J, Sigmon GE, Ward M, Roback N, Burns PC (2010) Syntheses, structures, and IR characterization of new uranyl sulfate/selenate 1D-chain, 2D-sheet and 3Dframework. Z Kristallogr 225: 230-239

NАкАмото K (1997) Infrared and Raman Spectra of Inorganic and Coordination Compounds. John Wiley \& Sons, New York, pp 1-387

SHELDRICK GM (2007) SADABS, Universität Göttingen (Germany)

Sheldrick GM (2008) A short history of SHELX. Acta Cryst A64: 112-122 